\title{
Cardiovascular Effects of Gasotransmitter Donors
}

\author{
M. CEBOVÁ ${ }^{1}$, M. KOŠÚTOVÁ ${ }^{1}$, O. PECHÁŇOVÁ ${ }^{1}$ \\ ${ }^{1}$ Institute of Normal and Pathological Physiology, Slovak Academy of Sciences, Bratislava, Slovak \\ Republic
}

Received August 24, 2016

Accepted September 12, 2016

\begin{abstract}
Summary
Gasotransmitters represent a subfamily of the endogenous gaseous signaling molecules that include nitric oxide (NO), carbon monoxide $(\mathrm{CO})$, and hydrogen sulphide $\left(\mathrm{H}_{2} \mathrm{~S}\right)$. These particular gases share many common features in their production and function, but they fulfill their physiological tasks in unique ways that differ from those of classical signaling molecules found in tissues and organs. These gasotransmitters may antagonize or potentiate each other's cellular effects at the level of their production, their downstream molecular targets and their direct interactions. All three gasotransmitters induce vasodilatation, inhibit apoptosis directly or by increasing the expression of antiapoptotic genes, and activate antioxidants while inhibiting inflammatory actions. NO and CO may concomitantly participate in vasorelaxation, anti-inflammation and angiogenesis. NO and $\mathrm{H}_{2} \mathrm{~S}$ collaborate in the regulation of vascular tone. Finally, $\mathrm{H}_{2} \mathrm{~S}$ may upregulate the heme oxygenase/carbon monoxide (HO/CO) pathway during hypoxic conditions. All three gasotransmitters are produced by specific enzymes in different cell types that include cardiomyocytes, endothelial cells and smooth muscle cells. As translational research on gasotransmitters has exploded over the past years, drugs that alter the production/levels of the gasotransmitters themselves or modulate their signaling pathways are now being developed. This review is focused on the cardiovascular effects of $\mathrm{NO}, \mathrm{CO}$, and $\mathrm{H}_{2} \mathrm{~S}$. Moreover, their donors as drug targeting the cardiovascular system are briefly described.
\end{abstract}

\section{Key words}

Nitric oxide $\bullet$ Carbon monoxide $\bullet$ Hydrogen sulphide $\bullet$ Heart $\bullet$ Vessels • Cardiovascular system

\section{Corresponding author}

M. Cebová, Institute of Normal and Pathological Physiology, Slovak Academy of Sciences, Sienkiewiczova 1, 81371 Bratislava, Slovak Republic. E-mail: martina.cebova@savba.sk

\section{Introduction}

Gasotransmitters are endogenously produced gaseous molecules that function as neurotransmitters and signal mediators to target enzymes, ion channels, and different transporters.

The physiological importance of the first molecule from the family of gasotransmitters, known as nitric oxide (NO), was recognized 30 years ago (Furchgott and Zawadzki 1980, Ignarro et al. 1988). The Nobel Prize in Physiology or Medicine has been awarded in 1998 for the discovery of "nitric oxide as a signaling molecule in the cardiovascular system". The class of endogenously generated gaseous transmitters includes also carbon monoxide $(\mathrm{CO})$ and hydrogen sulphide $\left(\mathrm{H}_{2} \mathrm{~S}\right)$ (Szabo 2010, Peers and Steele 2012). Other gaseous molecules such as ammonia or methane are also candidates for this class (Wang 2014). All of them were initially considered to be toxic; but it has recently been determined that at low levels the endogenous $\mathrm{NO}, \mathrm{CO}$, and $\mathrm{H}_{2} \mathrm{~S}$ may provide protective physiological roles within the cardiovascular system and compensatory modulations during cardiac stress and injury (Calvert et al. 2010). All three gases have been shown to modulate ischemia/reperfusion injury by inducing a number of cytoprotective mechanisms that include induction of vasodilatation, inhibition of apoptosis, modulation of mitochondrial respiration, activation of antioxidants, and 
inhibition of inflammation. While their actions are similar, there are some differences in the mechanisms by which these gasotransmitters induce their effects. NO and $\mathrm{CO}$ share at least one common mechanism of action: both activate soluble guanylate cyclase (sGC). The affinity of NO to sGC is, however, approximately 30 to 100 times greater than that of $\mathrm{CO}$ ( $\mathrm{Li}$ and Moore 2007). Yet there is no evidence that $\mathrm{H}_{2} \mathrm{~S}$ actually interacts with sGC. It has been suggested, however, that endogenous $\mathrm{H}_{2} \mathrm{~S}$ might increase the cGMP level by inhibiting PDE activity (Di Villa Bianca et al. 2015).

All three gasotransmitters are produced by specific enzymes. NO is produced by NO synthases (NOS) from the amino acid L-arginine. Three NOS isoforms, collectively known as NOS1, NOS2 and NOS3, were originally termed neuronal, inducible and endothelial NOS, respectively (Garvin et al. 2011). Recently, the effects of still putative mitochondrial NOS
(mtNOS) have been proposed (Zaobornyj and Ghafourifar 2012). CO is generated by heme oxygenases (HO) during heme degradation (Wu and Wang 2005). There are three heme oxygenases (HO-1-3) (Yoshida et al. 1974, Maines et al. 1986, McCoubrey et al. 1997). $\mathrm{H}_{2} \mathrm{~S}$ is mainly produced within the metabolism of L-cysteine by the enzymes cystathionine- $\beta$-synthase (CBS), cystathionine- $\gamma$-lyase (CSE or CTH) and 3-mercaptopyruvate sulfurtransferase (3-MST) (Wang 2012). Recently, an additional pathway for endogenous $\mathrm{H}_{2} \mathrm{~S}$ production has been described that involves D-cysteine, 3-MST, and D-amino acid oxidase (Shibuya et al. 2013).

This review is focused on the cardiovascular effects of three endogenously produced molecules termed as gasotransmitters: $\mathrm{NO}, \mathrm{CO}$, and $\mathrm{H}_{2} \mathrm{~S}$. Moreover, their donors as drug targeting the cardiovascular system are described.

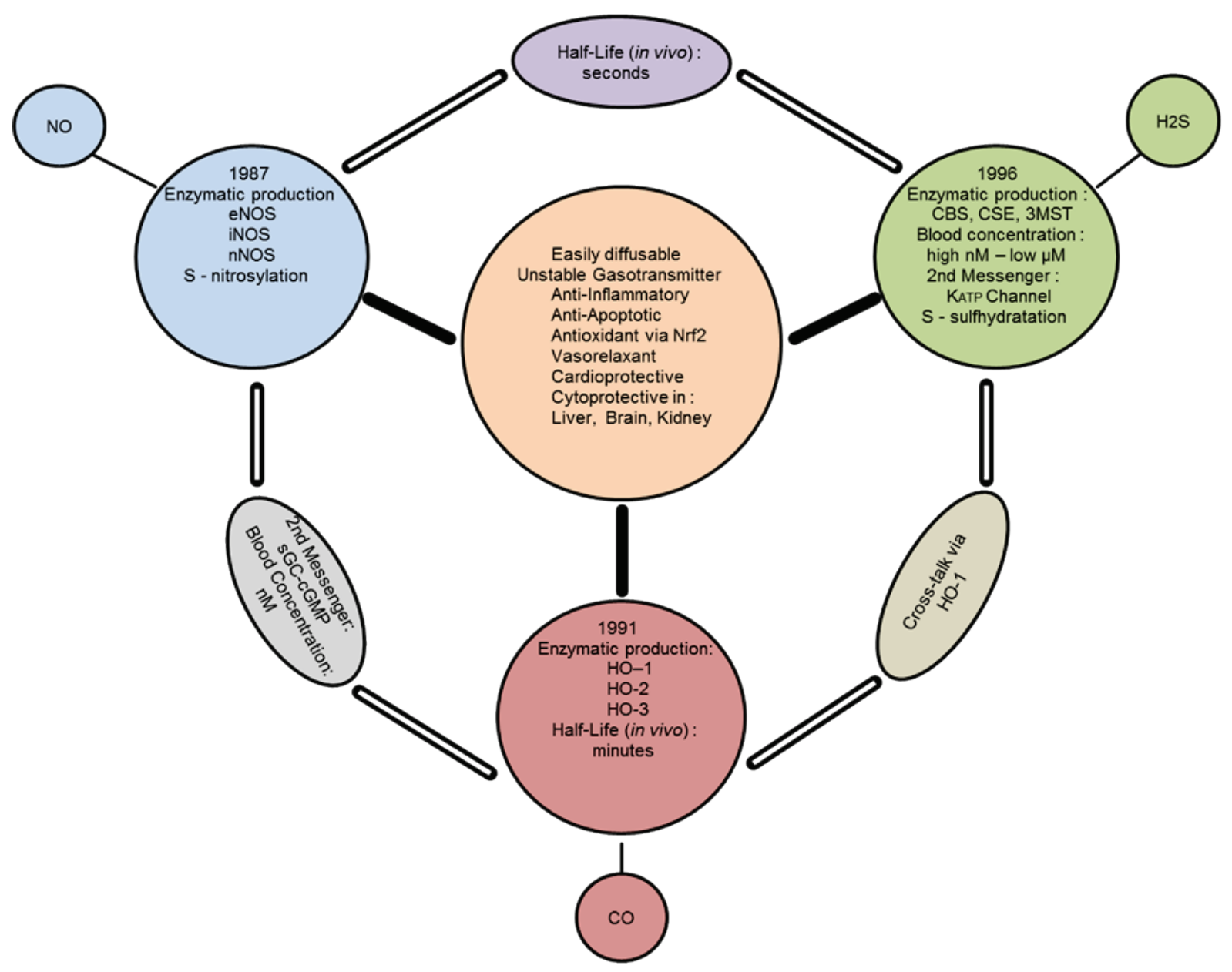

Fig. 1. The endogenous enzymatic production of nitric oxide (NO), carbon monoxide (CO) and hydrogen sulphide $\left(\mathrm{H}_{2} \mathrm{~S}\right)$ that provides effective cytoprotection via regulation of multiple signaling pathways. CBS, cystathionine $\beta$-synthase; cGMP, cyclic guanosine monophosphate; CSE, cystathionine $\mathrm{y}$-lyase; eNOS, endothelial nitric oxide synthase; HO-1, heme oxygenase 1 ; iNOS, inducible NOS; KATP, ATP-sensitive $\mathrm{K}^{+}$channel; 3MST, 3-mercaptopyruvate sulfurtransferase; nNOS, neuronal NOS; Nrf2, nuclear-factor-E2-related factor-2; sGC, soluble guanylyl cyclase. 


\section{NO in normal and pathological conditions}

Nitric oxide originates from the amino acid L-arginine. Its formation is catalyzed by one of three different isoforms of NOS that differ in enzymatic activity, regulation (transcriptional, translational, and posttranslational mechanisms), expression and compartmentalization in cells and tissues. Three distinct NOS isoforms are called NOS I, II, and III. These correspond to the inducible (iNOS), neuronal (nNOS), and endothelial (eNOS) isoforms, typically with high, medium, and low activities, respectively (Bredt and Snyder 1990, Förstermann et al. 1991). Still putative fourth isoform - mtNOS may represent a mechanism of fine regulation of the mitochondrial respiratory complexes (for review see Zaobornyj and Ghafourifar 2012). Particular isoforms were described in various cells of cardiovascular system including cardiomyocytes, endothelial cells, and vascular smooth muscle cells (Radomski et al. 1990, Schulz et al. 1992). Within the heart, eNOS is expressed predominantly in the coronary and cardiac endothelium, whereas nNOS is expressed in the cardiomyocytes (for review see Tirziu and Simons 2008, Pacher et al. 2007).

Nitric oxide may affect myocytes in a number of different ways. NO signaling via cGMP-dependent or independent pathways modulates the function of downstream proteins via specific posttranslational modifications such as phosphorylation by cGMPdependent protein kinase (PKG) or S-nitrosylation. Interestingly, an increase in intracellular cGMP induced by natriuretic peptides or cGMP analogues was recently shown to modulate both sarcolemmal and mitochondrial ATP-sensitive $\mathrm{K}^{+}$channel opening in ventricular cardiomyocytes, which suggests further, diverse actions of NO (Burley et al. 2014). The main physiological effects of NO derived from eNOS and nNOS include reduction of the contractile frequency of cardiomyocytes, attenuation of cardiac contractility, acceleration of relaxation and increasing distensibility of cardiomyocytes, and improvement of the efficiency of myocardial oxygen consumption. Under the conditions of enhanced cardiac reserve and cardiac hypertrophy, NO derived from eNOS modulates receptor-mediated signaling, which ultimately leads to a moderate inhibition of cardiac contractility (Yue and Yu 2011, Knowles et al. 2011). NO derived from the complex of nNOS-ryanodine receptor (RyR) stabilizes RyR calcium release and increases the efficiency of $\mathrm{Ca}^{2+}$ cycling in sarcoplasmic reticulum by the inhibitory effects. However, besides the above-mentioned inhibitions of NO derived from eNOS and nNOS, NO derived from iNOS generally prevents mitochondrial permeability transition pore opening by inhibiting mitochondrial respiration under the conditions of the myocardial ischemia-reperfusion injury and heart failure (Yue and Yu 2011).

In the endothelium, the interaction of eNOS with caveolin-1 in the caveolae is critical for eNOS activity (Feron and Balligand 2006). Endothelial NOS plays a key role in controlling blood flow and maintaining an antithrombotic and anti-inflammatory luminal surface. On the other hand, iNOS is induced by inflammatory stimuli in leukocytes, epithelial cells and macrophages to mediate pathogen killing. NO synthesized and released by vascular endothelial cells is an important regulator of vascular tone, leukocyte adhesion, platelet aggregation and vascular smooth muscle-cell proliferation (Balligand et al. 1993, Bolli et al. 1997, Buchwalow et al. 2001, Torres-Resgado et al. 2007). Interestingly, eNOS expression was not affected by cardiovascular risk factors such as hypertension, obesity, and insulin resistance (Bouvet et al. 2007, Fulton et al. 2004). Paradoxically, it was found to be increased in various pathological states that are associated with oxidative stress (Zhen et al. 2008, Ding et al. 2007, Li et al. 2002, Puzserova and Bernatova 2016). This effect might be partly mediated by limiting the availability of $\mathrm{NO}$, thereby exerting a negative feedback on NOS expression through the activation of nuclear factor kappa B (NF-kB) (Pechanova and Simko 2009, Pechanova and Simko 2010, Zhen et al. 2008, Vranková et al. 2009).

It is generally believed that increased production of ROS in the heart and vessels plays an important role in the pathology of hypertension and other cardiovascular diseases; but so far, the clinical studies that used different antioxidants have yielded rather contradictory results (for review see Pechanova and Simko 2009). For example, one of the largest studies involving more than twenty thousand individuals with high cardiovascular risk did not observe any reduction of blood pressure after five years of treatment with the combination of ascorbic acid, synthetic vitamin $\mathrm{E}$, and $\beta$-carotene. Moreover, substantially increased plasmatic concentrations of applied vitamins did not result in any significant reduction of the five-year morbidity and mortality from cardiovascular reasons (Heart Protection Study Collaborative Group 2002). Temporarily increased ROS generation in hypertension is not necessarily harmful, as 
it may stimulate the activity of the antioxidant defence system and improve the NO signaling pathway, resulting in the establishment of a new equilibrium between increased oxidative load and the stimulated NO pathways, thus maintaining sufficient $\mathrm{NO}$ availability (Dröge 2002, Pechanova and Simko 2010, Bernatova 2014). However, in hypertension associated with obesity or diabetes, ROS may favor the activation of proinflammatory NF-kB-dependent pathways. Under these conditions, activation of NF- $\mathrm{KB}$ increases levels of cytokines IL-6 and TNF- $\alpha$ that may affect the phosphorylation of tyrosine kinases and decrease NOS activity with a final decrease in NO generation (for review see Belin de Chantemele and Stepp 2012). The increased production of ROS and decreased availability of NO have been suggested to be responsible also for endothelial dysfunction in the models of hypertriglyceridemia (for review see Zicha et al. 2006). Several studies also reported prevention or improvement of endothelial dysfunction by different polyphenolic antioxidants and NO donors (Pechanova et al. 2006, Pechanova et al. 2015). Sufficient production of NO is therefore essential for the prevention and treatment of severe cardiovascular diseases.

\section{NO donors as a drug targeting cardiovascular system}

NO donors are pharmacologically active substances that either spontaneously release NO or are metabolized to NO or its redox congeners. NO donors may provide a wide scope for pharmacotherapy in cardiovascular medicine. The organic nitrates (glyceryl trinitrate, isosorbide mononitrate) and NO-metal complexes (sodium nitroprusside, diazeniumdiolates), S-nitrosothiols and (benzo) furoxans are the most commonly used NO donor drugs (Serafim et al. 2012). Glyceryl trinitrate (GTN, also known as nitroglycerin) is the best-studied nitrate. It is used mainly in relief of acute pain associated with angina. On the other hand, preparations with a slower NO release, such as isosorbide mononitrate (ISMN), are used for the treatment of chronic angina. The other clinically relevant NO donor is sodium nitroprusside (SNP). SNP is used for the rapid lowering of blood pressure in hypertensive crises and as the gold standard NO-dependent but endotheliumindependent vasodilator in clinical and experimental studies. The major complications of SNP therapy are hypotension and toxicity from accumulation of cyanide. These complications usually occur in patients with renal insufficiency when treated for more than $24 \mathrm{~h}$
(Hollenberg 2007, Thomas et al. 2009). S-nitrosothiols have far less stringent metabolic requirements, and this may be why they do not induce nitrate tolerance with long-term use. They have been shown to induce vasodilatation longer than other types of NO donors (Alencar et al. 2003, Nacharaju et al. 2012).

Nitrate tolerance, however, has become a limiting factor for clinical use of NO donors. Extended use of nitrate vasodilators induces nitrate tolerance that leads to tachyphylaxis and to aggressive side effects, including increased oxidative stress, endothelial dysfunction and cardiac autonomic dysfunction (EroyEveles and Mascharak 2009, Gori and Parker 2008). The tolerance has been shown to depend on the type of nitrate and the dosing schedule.

Molsidomine and pentaerythrityl tetranitrate (PETN) represent more effective tolerance devoid NO donors with a pharmacodynamically beneficial effect. Molsidomine belongs to the sydnonimines group, and it is metabolized to the active linsidomine. PETN is the nitrate ester of pentaerythritol. It is structurally very similar to nitroglycerin. It was found to be the most active drug in cGMP production and in following pathway activation. PETN does not induce oxidative stress (Hinz et al. 1998) and evokes endothelium-independent dilatation of the arterial wall (Megson and Leslie 2009). Nicorandil is another vasodilator that is commonly used to treat chronic stable angina. Unlike nitrates, the actions of nicorandil result in "balanced" arterial and venous dilatation that is mediated via two distinct anti-angina mechanisms (Kukowetz et al. 1991). In addition, nicorandil is not associated with tolerance or rebound angina, and there is some evidence to suggest prognostic benefit due to reduction in oxidative stress during myocardial ischemic reperfusion injury (Horinaka 2011) and the infarct size in rabbit hearts (Argaud et al. 2009).

LA 419 is NO donor that has been designed to treat clinical conditions associated with reduced bioavailability of NO (Lacer 2005). The compound LA-419 is an analogue of isosorbide mononitrate. It has been showed to exert anti-ischemic, anti-thrombotic, and anti-atherosclerotic cardiac actions (Lacer 2005, Vilahur et al. 2004). Preclinical studies have shown that this agent possesses anti-atherogenic and antioxidant properties that make it applicable for the oral treatment of chronic cardiovascular disorders. LA-419 has beneficial effects in preventing the progression to maladaptive cardiac hypertrophy in a well-characterized model of left ventricle hypertrophy by pressure overload. Ruiz-Hurtado 
and Delgado (2010) demonstrate that LA-419 prevents left ventricular remodeling in rats with aortic stenosis at doses that do not affect arterial blood pressure. In their experiment, LA-419 even restored cardiac eNOS expression and enhanced the interaction between eNOS and its positive regulator - heat shock protein 90. LA-419 also re-established the normal cardiac levels of cGMP. In addition, the thiol group of LA-419 improved NO stability by converting NO into nitrosothiols and by protecting the formed NO from the reaction with ROS (for review see Pechanova et al. 2015).

Until now, there are several clinical trials that verify the therapeutic potential of NO donors. In general, most of them that focus on pathologies are connected with the cardiovascular system. There is no "typical" NO donor. Each has its own specific characteristics that determine the rate of $N O$ release, peak $N O$ concentration and NO-related species generated for a particular application. Nevertheless, further studies that reveal the complex influence on vascular cell homeostasis are needed to find the key to successful therapeutic use of NO donors.

\section{CO in normal and pathological conditions}

Carbon monoxide is a biologically active molecule and is uniquely well established as a gasotransmitter, being a more stable molecule than NO or $\mathrm{H}_{2} \mathrm{~S}$. Specific molecular targets of $\mathrm{CO}$ are still not known but it acts as a signaling molecule in the cardiovascular, nervous and gastrointestinal systems (Beltowski et al. 2004, Olas 2014). CO is the most biologically stable gasotransmitter due to its weak chemical reactivity. CO does not have unpaired electrons, and does not chemically dissociate in an aqueous solution to form different chemical species. Thus, $\mathrm{CO}$ might be capable of exerting its effects during longer time periods and distances compared to $\mathrm{NO}$ or $\mathrm{H}_{2} \mathrm{~S}$ (Untereiner et al. 2012).

Endogenous $\mathrm{CO}$ is generated by heme oxygenases (HO-1 and HO-2) as a final product of heme degradation. The cascade of the reactions leads to the production of ferrous iron $\left(\mathrm{Fe}^{2+}\right), \mathrm{CO}$ and biliverdin, which is rapidly degraded to bilirubin. $\mathrm{O}_{2}$ and NADPH are necessary for this reaction, which is crucial to iron and bile metabolism, and also induces a production of an effective antioxidant bilirubin. HO-1 expression is inducible, whereas HO-2 expression is constitutive. Both atrial and ventricular cardiac myocytes express $\mathrm{HO}-1$ and HO-2
(Peers and Steele 2012). Just like NO, CO has been shown to act through the activation of sGC increasing cGMP concentrations (Schmidt 1992). However, its effect has lower potential than that modulated by NO (Stone and Marletta 1994, Ma et al. 2007). Moreover, there is a fundamental difference in the reactivity of CO compared to $\mathrm{NO}$ and $\mathrm{H}_{2} \mathrm{~S}$ (Fukuto et al. 2012). CO binds to transition metal centers due to ambient pressure and temperature and in the absence of special catalysts, whereas the other two species react rapidly with both metal centers and many of the organic constituents of biological systems. This relative inertness and selective reactivity of $\mathrm{CO}$ has special implications for both the cellular target structures of $\mathrm{CO}$ and the development of delivery systems for $\mathrm{CO}$ in potential therapeutic applications (Motterlini and Otterbein 2010). It has been proven that $\mathrm{CO}$ is able to activate big-conductance calcium-activated potassium channels with consequent hyperpolarization and relaxation of arterial membrane (Wang et al. 1997).

$\mathrm{CO}$ is able to modulate important signaling pathways that involve $\mathrm{NO} / \mathrm{GC}, \mathrm{K}^{+}$channels, ROS and MAPKs. The relevant biosynthetic enzyme, heme oxygenase, has a central role in a cellular antioxidant defence and vascular protection, and it may mediate many actions of drugs used in cardiovascular therapy (Muchova et al. 2007). Up-regulated HO-1 is expressed in the myocardium and in the coronary circulation after stress such as ischemia/reperfusion ( $\mathrm{I} / \mathrm{R})$, and it has cardioprotective (Johnson et al. 2004, Peers and Steele 2012), anti-apoptotic and cytoprotective effects (Stein et al. 2012, Muchova et al. 2007, Chan et al. 2011). Endothelium and smooth muscle of arterial and venous blood vessels express constitutively HO-2 which may regulate the endogenous $\mathrm{CO}$ production and thus modulate the vascular tone.

Among the consequences of $\mathrm{HO} / \mathrm{CO}$ system dysfunction belong increased vascular contractility, unbalanced cellular apoptosis and proliferation in the vascular wall, increased oxidative stress, and hypertension development. Acute application of pharmacological inducers to upregulate the expression of HO-1 or the use of gene delivery method to overexpress HO-1 decreased blood pressure in young spontaneously hypertensive rats (SHR). However, acute manipulation with the expression of HO-1 has not been successful in decreasing blood pressure in adult SHR (Ndisang et al. 2004, Mustafa and Johns 2001). HO-1 expression in vascular tissues has been found to be decreased in SHR at a prehypertensive stage. Furthermore, the activities of the 
downstream targets of $\mathrm{CO}$ - including soluble guanylate cyclase - were also decreased in prehypertensive SHR. These findings show that suppression of HO-1/CO/cGMP signaling pathway precedes the development of hypertension and should support the rise of blood pressure in SHR (Ndisang and Wang 2002). The HO/CO system has also been studied in other models of hypertension, such as Dahl salt-sensitive, phenylephrine-, angiotensin II- and L-NAME-induced hypertension (Teran et al. 2005, Johnson et al. 1996, Johnson et al. 2004, Aizawa et al. 2000, Soni et al. 2010). Teran et al. (2005) suggested that hypertension and surprisingly HO-mediated endothelial dysfunction develop gradually and simultaneously in Dahl salt-sensitive rats on high-salt diets. They also suggested that HO-derived CO underlies the impaired endothelial dysfunction and contributes to hypertension in Dahl salt-sensitive rats on high-salt diets. Johnson et al. (2004) also documented that cardiac HO-1 is overexpressed in Dahl salt-sensitive rats. They have also shown that arterial HO-1 immunostaining is enhanced in rats on high-salt diet, but they proposed that coronary HO-1 expression is increased to support coronary vasodilatation in salt-induced hypertension. Also the treatment with the heme oxygenase inducer, heme-L-lysinate, that stimulates formation of heme oxygenase products, reduced blood pressure in rats. Heme-L-lysinate lowered arterial pressure in deoxycorticosterone acetate-salt hypertensive rats and in rats with phenylephrine-induced hypertension, indicating that the vasodepressive actions of heme and $\mathrm{CO}$ may be extended to other hypertensive models (Johnson et al. 1996). Ndisang et al. (2014) offered novel sights on the cardio-protective role of upregulating heme-oxygenase in L-NAME hypertension. The treatment with the heme oxygenase inducer, heme-arginate, improved myocardial morphology in L-NAME hypertensive rats by reducing subendocardial injury, interstitial fibrosis, mononuclearcell infiltration and cardiomyocyte hypertrophy. Soni et al. (2010) concluded that CO-dependent cardioprotective effects seem to be NO-independent because NOS inhibition by L-NAME did not affect CO-mediated protection in isolated perfused rat heart. The upregulation of the $\mathrm{HO} / \mathrm{CO}$ system, which is followed by increased production of endogenous $\mathrm{CO}$, also increased the concentration of biliverdin and bilirubin, which are considered to be potent antioxidants. Increased concentration of $\mathrm{CO}$ can invoke the inhibition of abnormal vascular contractility and vascular remodeling (Rochette et al. 2013). Moreover, Aizawa et al. (2000) have found that HO-1 upregulation in the kidney of Ang II-induced hypertensive rats can perform a renoprotective effect against Ang II-induced renal injury.

Higher CO levels decrease the production of $\mathrm{NO}$ and the formation of $\mathrm{ONOO}^{-}$in the cardiovascular system (Munoz-Sanchez and Chanez-Cardenas 2014, Throup et al. 1999). Cardiotoxic effects of CO cause ischemic and endothelial damage and oxidative stress in the heart (Lippi et al. 2012). Long-term CO exposure leads to cardiac fibrosis following myocardial cell death. During experimental $\mathrm{CO}$ exposure the cardiac remodeling was accompanied by the alterations in $\mathrm{Ca}^{2+}$ homeostasis, uncoupling of eNOS, and pro-arrhythmic changes in cardiac electrophysiology (Reboul et al. 2012). Thus, it seems that similarly like NO, CO-induced effects are strongly dependent on the concentration of this gasotransmitter.

\section{CO donors as a drug target for cardiovascular system}

Carbon monoxide-releasing molecules (CORMs) are molecules that can release $\mathrm{CO}$ under certain biological conditions. The two major classes of CORMs are boranocarbonates and metal carbonyl complexes that contain ruthenium, iron or manganese as metal center (Mann 2010, Motterlini et al. 2005, Pitchumony et al. 2010, Zobi 2013). CORMs release CO via thermal activation or hydrolysis in biological buffers (Desmard et al. 2012). In spite of the wide range of therapeutic studies that show the beneficial effects of $\mathrm{CO}$ administered as a gas or as a CORM in cardiovascular disease, most of them to date have focused only on the commercially available CORM-2 and water-soluble CORM-3.

CORM-2 (tricarbonyldichlororuthenium(II)) $\left(\left[\mathrm{Ru}(\mathrm{CO})_{3} \mathrm{Cl}_{2}\right]_{2}\right)$ is the first ruthenium-based CO-releasing molecule with solubility in organic solvents. CORM-2 has a vasorelaxing effect in a concentration-dependent manner on isolated aortic ring sections or afferent renal arterioles (Botros and Navar 2006, Motterlini et al. 2002, Marazioti et al. 2011, Decaluwé et al. 2012). It has been shown that the inhibitor of the guanylate cyclase, quinoxalin-1-one, reduces CORM-2 effect via the sGC-cGMP pathway (Motterlini et al. 2003, Marazioti et al. 2011, Decaluwé et al. 2012). $\mathrm{K}^{+}$channels also contribute to CORM-2induced vasodilatation. It has been proven that $\mathrm{CO}$ is able to work directly on $\mathrm{Ca}^{2+}$-activated $\mathrm{K}^{+}$channels. However, CORM-2 up-regulates the voltage-dependent $\mathrm{K}^{+}$channels in mice thoracic aorta (Wang et al. 1997, Decaluwé et al. 
2012). However, CO-induced inhibition of $\mathrm{sGC}$ and $\mathrm{K}^{+}$channels did not cause an obvious inhibition of CORM-2-induced vasorelaxation (Decaluwé et al. 2012). The relaxant abilities of CORM-2 may have a blood pressure lowering effect in vivo. CORM-2 applied in a rat model of acute hypertension significantly attenuated L-NAME-induced pressor responses and induced significant vasorelaxation of thoracic aorta (Motterlini et al. 2012). Exercise training in hypertensive rats completely renewed the impaired relaxant responses of CORM-2 due to an increased activity of $\mathrm{K}^{+}$channels (Boissiere et al. 2006). In a rat model of myocardial ischemia-reperfusion injury it has been shown that cardioprotection by CORM-2 is highly concentrationdependent, but independent of coronary endothelium and this cardioprotective effect might be attributed to the activation of $\mathrm{K}_{\mathrm{ATP}}$ channel present on vascular smooth muscle cells (VSMC) (Soni et al. 2010). Another study has described the mechanisms of cardioprotection that occur as a result of the activation of the p38 mitogenactivated protein kinase $\beta$ and protein kinase $C$ cascades before ischemia and phosphatidylinositol 3-kinase cascade during reperfusion (Soni et al. 2012). Moreover, CORM-2 protected cardiomyocytes from I/R-induced apoptosis as well. This probably occurs through the inhibition of mitochondrial apoptotic pathway and by the enhancement of energy metabolism (Zhao et al. 2014). After the post-resuscitation phase, CORM-2 eliminated the production of cardiac reactive oxygen species in mitochondria and reduced oxidative stress in the heart (Yao et al. 2015).

CORM-3 (tricarbonylchloro(glycinato)ruthenium(II)) $\left(\mathrm{Ru}(\mathrm{CO})_{3} \mathrm{Cl}(\right.$ glycinate $)$ seems to become the most promising $\mathrm{CO}$ donor due to its high ability to release $\mathrm{CO}$ and to mediate vasorelaxation (Motterlini et al. 2003). Vascular effect was also demonstrated by the low response to iCORM-3 (inactivated CORM-3 which is depleted of $\mathrm{CO}$ ). CORM-3-dependent relaxation was significantly reduced by blocking the $\mathrm{K}_{\mathrm{ATP}}$ channels with glibenclamide or by blocking the sGC activity with ODQ. This confirms that $\mathrm{K}^{+}$channel activation and cGMP partially mediate CORM-3 effect. Interestingly, inhibiting NO production or removing the endothelium significantly decreased vasodilatation by CORM-3, suggesting that factors produced by the endothelium influence CORM-3 vascular activities (Foresti et al. 2004). However, Alshehri et al. (2013) demonstrated that the foregoing hypotheses are unlikely to make clear the endotheliumdependent and cGMP-dependent relaxant influence of
CORM-3 that results from the stimulation of $\mathrm{NO}$ synthase. They also find that CORM-3 has a vasorelaxant effect that is independent of endothelium and sGC by direct activation of smooth muscle $\mathrm{K}^{+}$channels. In addition, CORM-3 causes vasorelaxation in vivo followed by a rapid decline in mean arterial pressure, which is further enhanced by 3-(50-hydroxymethyl-20-furyl)-1benzyl indazole (YC-1). This substance is known to sensitize sGC to the activation by $\mathrm{CO}$, confirming the engagement of sGC (Foresti et al. 2004, Motterlini et al. 2005). Pretreatment with $1 \mathrm{H}-[1,2,4]$ oxadiazolo [4,3-a] quinoxalin-1-one (ODQ) or charybdotoxin eliminated the CORM-3-induced relaxation in aortas of normotensive and spontaneously hypertensive rats. This indicates a participation of $\mathrm{sGC}$ and $\mathrm{Ca}^{2+}$-activated $\mathrm{K}^{+}$channels, respectively. Compared with the NO donor, S-nitroso-Nacetyl-D,L-penicillamine, CORM-3-mediated vascular relaxation was maintained for a longer time in SHR aortas. Therefore, CORM-3 is a possible alternative for the treatment of hypertension when the NO donor therapy is not adequate (Failli et al. 2012). CO from CORM-3 displayed a positive inotropic effect on isolated perfused rat cardiac tissue. In this case, cGMP and stimulation of $\mathrm{Na}^{+} / \mathrm{H}^{+}$exchanger seem to be involved (Musameh et al. 2006). CORM-3 also reduced the release of myocardial creatine kinase and attenuated the infarct size (Clark et al. 2003). It has cardioprotective effects not only when given at the moment of reperfusion but also when administered 24 to 72 hours before coronary occlusion. This persistent cardioprotective effect of CORM-3 may be helpful as prevention in patients at risk for myocardial infarction (Stein et al. 2005). In a mouse model of myocardial infarction, CORM-3 eliminated cardiac tissue damage, decreased infarct size during reperfusion and even significantly prolonged the survival period after organ transplantation (Clark et al. 2003).

CORMs are novel CO-specific carriers that can be used in pharmacology for their therapeutic effects. To fully reflect the promise of $\mathrm{CO}$ as a therapeutic agent, it is essential to find the novel pathway for $C O$ delivery to injured tissues without concomitant formation of elevated toxic blood levels of carboxyhemoglobin. CORMs appear to have a potential to constitute safe treatments with controlled $\mathrm{CO}$ release.

\section{$\mathrm{H}_{2} \mathrm{~S}$ in normal and pathological conditions}

Hydrogen sulphide $\left(\mathrm{H}_{2} \mathrm{~S}\right)$ is easily soluble gas in both water and lipids. At physiological $\mathrm{pH}$, less than 
$20 \%$ of $\mathrm{H}_{2} \mathrm{~S}$ exists as an undissociated compound; the rest is dissociated to $\mathrm{HS}^{-}$and $\mathrm{H}^{+}(\mathrm{Li}$ and Lancaster 2013). From a chemical point of view, $\mathrm{H}_{2} \mathrm{~S}$ is the simplest thiol of all. Until recently, $\mathrm{H}_{2} \mathrm{~S}$ was viewed exclusively as a toxic gas and environmental hazard. In general, $\mathrm{H}_{2} \mathrm{~S}$ damages mainly the brain, kidneys and lungs. However, $\mathrm{H}_{2} \mathrm{~S}$ is an endogenous, labile molecule that induces a variety of beneficial reactions in the myocardium (Pan et al. 2006). Four enzymatic pathways of $\mathrm{H}_{2} \mathrm{~S}$ production have been found to date. Two are catalyzed by cystathionine $\beta$-synthase (CBS) and cystathionine $\gamma$-lyase (CSE), which are pyridoxal 5 '-phosphate-dependent cytosolic enzymes of the transsulfuration pathway in which homocysteine is metabolized to cysteine (for review see Beltowski 2015). In general, it is suggested that CBS is the main $\mathrm{H}_{2} \mathrm{~S}$ synthase in the nervous system. CSE plays this role in the most peripheral tissues except the liver and kidney, which contain both enzymes in substantial amounts (Singh et al. 2009). The third pathway of $\mathrm{H}_{2} \mathrm{~S}$ generation requires two enzymes: cysteine aminotransferase (CAT) and 3-mercapto-pyruvate sulfurtransferase (3-MST). This pathway operates mainly in mitochondria (Kimura 2013). 3-MST is presented in endothelial cells in the thoracic aorta (Shibuya et al. 2009). The distribution and regulation of $\mathrm{H}_{2} \mathrm{~S}$-producing enzymes and the wide range of biological effects of $\mathrm{H}_{2} \mathrm{~S}$ are discussed in separate reviews (Szabo 2007, Elsey et al. 2010, Gadalla and Snyder 2010, Kimura 2014, Whiteman and Winyard 2011, Whiteman et al. 2011, Wang 2012, Cacanyiova et al. 2016). Like the other two gasotransmitters (NO and $\mathrm{CO}$ ), many of the biological responses to $\mathrm{H}_{2} \mathrm{~S}$ follow a biphasic dose-response: The effects of $\mathrm{H}_{2} \mathrm{~S}$ range from physiological, cytoprotective effects at low concentrations up to cytotoxic effects at higher concentrations (Szabo et al. 2014). There is growing evidence that $\mathrm{H}_{2} \mathrm{~S}$ is a critical regulator of cardiovascular functions and plays a protective role in the pathogenesis and development of cardiovascular diseases (Polhemus and Lefer 2014). Hydrogen sulphide may inhibit platelet activation and vascular smoothmuscle cell proliferation. In the vascular wall, $\mathrm{H}_{2} \mathrm{~S}$ functions as an endothelium-derived relaxing factor (Yang et al. 2008, Wang 2009). It is also an endothelium-derived hyperpolarizing factor (Tang et al. 2013, Mustafa et al. 2011). Altaany et al. (2014) suggested that hydrogen sulphide increases the phosphorylation of eNOS and thus reduces blood pressure. Thus, $\mathrm{H}_{2} \mathrm{~S}$ is a pivotal gasotransmitter that coordinates the S-sulfhydration, S-nitrosylation, and phosphorylation of eNOS to finely tune endothelial function under physiological and pathophysiological conditions.

$\mathrm{H}_{2} \mathrm{~S}$ relaxes the thoracic aorta, but its relaxation effect was significantly weaker than its effect on vena portae or ileum (Hosoki et al. 1997). Furthermore, endothelium-dependent vasorelaxation effects of $\mathrm{H}_{2} \mathrm{~S}$ are more prominent in peripheral resistance arteries than they are in large-conduit arteries, which require membrane hyperpolarization of both endothelial and vascular smooth muscle cells (Mustafa et al. 2011). Hosoki et al. (1997) and others have also found the synergic effect of $\mathrm{NO}$ and $\mathrm{H}_{2} \mathrm{~S}$. To date, mechanisms of primary hypertension have not been fully understood. $\mathrm{NO}$ and $\mathrm{CO}$ have been found to play important roles in the pathogenesis of hypertension, as mentioned above. But does $\mathrm{H}_{2} \mathrm{~S}$ also play a role in spontaneous hypertension? A variety of studies have focused on the association of $\mathrm{H}_{2} \mathrm{~S}$ with hypertension (Yang et al. 2008, Pan et al. 2015, Ahmad et al. 2012, Zhong et al. 2003). Intravenous bolus injection of $\mathrm{H}_{2} \mathrm{~S}$ induced a transient dose-dependent decrease in mean arterial pressure in anesthetized rats (Zhao et al. 2001). The CSE-deficient mice developed severe endothelial dysfunction and hypertension within 8 weeks of birth; however, $\mathrm{H}_{2} \mathrm{~S}$ replacement reduced systolic blood pressure in both $\mathrm{CSE}^{-/}$and $\mathrm{CSE}^{+/}$mice (Yang et al. 2008). These authors suggested that the $\mathrm{H}_{2} \mathrm{~S}$ synthases $/ \mathrm{H}_{2} \mathrm{~S}$ pathway confers a protection against hypertension. In SHR CSE gene expression was downregulated in the development of hypertension and plasma level of $\mathrm{H}_{2} \mathrm{~S}$, as well as its production rate were lower in SHR than in WKY rats. Therefore, CSE is a specific enzyme for $\mathrm{H}_{2} \mathrm{~S}$ production in the thoracic aorta, and its decreased activity in hypertension may lead to a smaller $\mathrm{H}_{2} \mathrm{~S}$ production. It can result in a decrease of circulating $\mathrm{H}_{2} \mathrm{~S}$ (Yan et al. 2004). Administration of exogenous $\mathrm{H}_{2} \mathrm{~S}$ lowers blood pressure and prevents the progression of diabetic nephropathy in SHR (Ahmad et al. 2012). Exogenous $\mathrm{H}_{2} \mathrm{~S}$ effectively inhibited the development of L-NAME-induced hypertension in rats (Zhong et al. 2003).

In vitro, $\mathrm{H}_{2} \mathrm{~S}$ and $\mathrm{NaHS}$ relaxed rat thoracic aorta and portal veins preconstricted with norepinephrine. Importantly, $\mathrm{H}_{2} \mathrm{~S}$ also relaxed mesenteric arteries (Cheng et al. 2004) which are as peripheral resistance vessels more significant for the regulation of vascular resistance and blood pressure than large conduit arteries. 


\section{$\mathrm{H}_{2} \mathrm{~S}$ donors as a drug target for cardiovascular system}

Potential targets for $\mathrm{H}_{2} \mathrm{~S}$ donors include arterial hypertension, atherosclerosis, myocardial hypertrophy, heart failure, ischemia-reperfusion injury of various organs such as the heart, brain, kidney, lung, liver or intestine (Kashfi and Olson 2013, Sikora et al. 2014). $\mathrm{H}_{2} \mathrm{~S}$ donors have also been shown to prevent platelet aggregation (Zhong et al. 2014) and thrombus formation in venules (Kram et al. 2013).

In most studies, the inorganic sulphide salts, sodium hydrosulphide (NaHS) and sodium sulphide $\left(\mathrm{Na}_{2} \mathrm{~S}\right)$ are used. These compounds increase $\mathrm{H}_{2} \mathrm{~S} / \mathrm{HS}^{-}$ concentration due to dissociation and $\mathrm{pH}$-dependent balance between $\mathrm{HS}^{-}$and $\mathrm{H}_{2} \mathrm{~S}$ in aqueous solutions. There are many mechanisms involved in the protective effect of NaHS, such as activation of $\mathrm{K}_{\text {ATP }}$ channels and protein kinase $\mathrm{B} / \mathrm{Akt}$, increase in $\mathrm{Nrf2}$ signaling. Yan et al. (2004) showed that, after injecting NaHS for 5 weeks, the plasma level of $\mathrm{H}_{2} \mathrm{~S}$, the production rate of $\mathrm{H}_{2} \mathrm{~S}$ and the CES expression in aorta of NaHS-treated SHR were increased significantly compared to those of control SHR. Also, systolic blood pressure decreased much at the same time and the medial cross-sectional area and medial stress were reduced, suggesting that aortic structural remodeling is attenuated by the increased level of $\mathrm{H}_{2} \mathrm{~S}$ in SHR. Other investigators showed that daily treatment of SHR with NaHS for 8 weeks not only lowered blood pressure but also reduced the hypertrophy of intramyocardial arterioles and ventricular fibrosis in these animals. These results suggest a long-term vasculoprotective effect of $\mathrm{H}_{2} \mathrm{~S}$ (Shi et al. 2007). Similar data have been reported by Zhao et al. (2008) who noted that chronic NaHS administration in SHR reduced aortic collagen-1 content and ${ }^{3} \mathrm{H}$-proline incorporation.

To overcome the limitation of sulphide salts, several slow-releasing $\mathrm{H}_{2} \mathrm{~S}$ compounds have been synthesized: namely, GYY4137, AP67, and AP72. GYY4137 (morpholin-4-ium 4-methoxyphenyl (morpholino) phosphinodithioate dichloromethane complex) is the most popular among the slow-releasing $\mathrm{H}_{2} \mathrm{~S}$ donors. It is a water soluble compound that spontaneously decomposes to release $\mathrm{H}_{2} \mathrm{~S}$ over 3-4 hours after dissolving. Its intravenous injection had no immediate effect on blood pressure in the anesthetized rat but caused a slow fall in blood pressure for up to 2 hours accompanied by a progressive, presumably reflex, rise in heart rate ( $\mathrm{Li}$ et al. 2008). The authors also found that GYY4137 induced vasorelaxation in vitro and decreased blood pressure in vivo. It reduced secretion of proinflammatory cytokines (TNF- $\alpha$, IL-1 $\beta$, IL-6) and decreased COX-2 and iNOS expression in LPSstimulated RAW264.7 macrophages (Whiteman et al. 2010). It also protected cultured cardiomyocytes from hyperglycemia-induced injury (Wei et al. 2014), was beneficial in the experimental model of joint inflammation ( $\mathrm{Li}$ et al. 2013), inhibited platelet aggregation in vitro and thrombus formation in vivo (Grambow et al. 2014), restored fetal growth in mice model of preeclampsia (Wang et al. 2013), and reduced atherosclerotic lesions in apo-E knockout mice (Liu et al. 2013). This inhibitor did not cause cytotoxic effects or alterations in the cell-cycle profile or p53 expression of cultured rat vascular smooth muscle cells (Li et al. 2008).

AP67 (4-methoxyphenyl) pyrrolidin-1-ylphosphinodithioc acid and AP72 (4-methoxyphenyl) piperidin-1-ylphosphinodithioc acid can relax precontracted isolated bovine ciliary artery, an effect that is dependent on endogenous production of $\mathrm{H}_{2} \mathrm{~S}$ (Kulkarni-Chitnis et al. 2015). AP39, a sulphide donor with a mitochondria-targeting moiety, has been shown to increase intracellular $\mathrm{H}_{2} \mathrm{~S}$ probe 7-azido-4-methylcoumarin. It has also been demonstrated that AP39 is able to prevent glucose oxidase-induced mitochondrial oxidative stress (Szczesny et al. 2014).

There is a growing evidence of the development and usage of the stable $\mathrm{H}_{2} \mathrm{~S}$ donors. These compounds seem to be innovative pharmacotherapentical tools for treatment of cardiovascular diseases.

\section{Conclusions}

$\mathrm{NO}, \mathrm{CO}$ and $\mathrm{H}_{2} \mathrm{~S}$ are endogenous gaseous transmitters with different physiological functions. As NO is the most extensively characterized of these transmitters, its properties have portended features of the others. So far it has been shown that all three gasotransmitters induce vasodilatation by activating the sGC/cGMP pathway (NO and $\mathrm{CO}$ ) or by activating ATPsensitive $\mathrm{K}^{+}\left(\mathrm{K}_{\text {ATP }}\right)$ channels $\left(\mathrm{H}_{2} \mathrm{~S}\right)$, they inhibit apoptosis directly or by increasing the expression of antiapoptogens such as HSP90, HSP70, and Bcl-2, and they activate antioxidants while inhibiting inflammatory actions. Regarding the crosstalk of gasotransmitters, $\mathrm{CO}$ and NO have been shown to participate in vasoactivity, influencing growth factors, anti-inflammatory mediators, angiogenesis and vascular remodeling. It has been suggested that $\mathrm{NO}$ and $\mathrm{H}_{2} \mathrm{~S}$ collaborate in the regulation of vascular homeostasis and vasodilatation. Finally, $\mathrm{H}_{2} \mathrm{~S}$ 
can upregulate the $\mathrm{HO} / \mathrm{CO}$ pathway during hypoxic pulmonary hypertension.

The role of exogenously derived NO has been studied by the administration of $\mathrm{NO}$ in the form of authentic NO gas, NO donors, and more recently by nitrite and nitrate. Currently, NO donors represent important drugs in cardioprotection and in the treatment of cardiovascular diseases. $\mathrm{CO}$ and $\mathrm{H}_{2} \mathrm{~S}$ donors are now extensively studied in animal models and human studies. It is expected that the high level of research activity in this area will transpire soon to a new set of pharmaceuticals with protective or therapeutic properties in the cardiovascular system.

\section{Conflict of Interest}

There is no conflict of interest.

\section{Acknowledgements}

This paper was elaborated within the projects APVV0742-10, APVV-14-0932, VEGA 2/0144/14 and 2/0195/15.

\section{Abbreviations}

3-MST - 3-mercaptopyruvate sulfurtransferase

AP39 - [(10-oxo-10-(4-(3-thioxo-3H-1,2-dithiol-5yl) phenoxy)decyl) triphenylphosphonium bromide]

AP67 - (4-methoxyphenyl) pyrrolidin-1-ylphosphinodithioc acid

AP72 - (4-methoxyphenyl) piperidin-1-ylphosphinodithioc acid

$\mathrm{CAT}$ - cysteine aminotransferase

CBS - cystathionine- $\beta$-synthase

cGMP - cyclic guanosine monophosphate

$\mathrm{CO}$ - carbon monoxide

CORMs - carbon monoxide-releasing molecules

COX - cyclooxygenase

CSE or CTH - cystathionine- $\gamma$-lyase

eNOS - endothelial NOS

GTN - glyceryl trinitrate
GYY4137 - morpholin-4-ium 4-methoxyphenyl (morpholino) phosphinodithioate

$\mathrm{H}_{2} \mathrm{~S}$ - hydrogen sulphide

$\mathrm{HO}$ - heme oxygenases

$\mathrm{HO} / \mathrm{CO}$ - heme oxygenase/carbon monoxide

$\mathrm{HS}^{-}$- bisulfide

HSP - heat shock protein

$\mathrm{I} / \mathrm{R}$ - ischemia/reperfusion

IL-1 $\beta$ - interleukin-1beta

IL-6 - interleukin 6

iNOS - inducible NOS

ISMN - isosorbide mononitrate

$\mathrm{K}_{\text {ATP }}$ - ATP-sensitive $\mathrm{K}^{+}$channel

L-NAME - N-nitro-L-arginine methylester

MAPKs - mitogen-activated protein kinases

mtNOS - mitochondrial NOS

$\mathrm{Na}_{2} \mathrm{~S}$ - sodium sulphide

NaHS - sodium hydrosulphide

nNOS - neuronal NOS

$\mathrm{NO}$ - nitric oxide

$\mathrm{NO} / \mathrm{GC}$ - nitric oxide-sensitive guanylyl cyclase

NOS - nitric oxide synthase

Nrf2 - nuclear-factor-E2-related factor-2

ODQ - 1H-[1,2,4] oxadiazolo [4,3-a] quinoxalin-1-one

$\mathrm{ONOO}^{-}$- peroxynitrite

PETN - pentaerythrityl tetranitrate

$\mathrm{PKB} / \mathrm{Akt}$ - protein kinase B or Akt

$\mathrm{PKG}$ - cGMP-dependent protein kinase

ROS - reactive oxygen species

$\left(\left[\mathrm{Ru}(\mathrm{CO})_{3} \mathrm{Cl}_{2}\right]_{2}\right)$ - tricarbonyldichlororuthenium(II) dimer $\left(\mathrm{Ru}(\mathrm{CO}){ }_{3} \mathrm{Cl}\right.$ (glycinate), tricarbonylchloro (glycinato)ruthenium(II)

RyR - ryanodine receptor

sGC - soluble guanylate cyclase

SHR - spontaneously hypertensive rats

SNP - sodium nitroprusside

TNF- $\alpha$ - tumor necrosis factor alpha

YC-1 - 3-(50-hydroxymethyl-20-furyl)-1-benzyl indazole

\section{References}

AHMAD FU, SATTAR MA, RATHORE HA, ABDULLAH MH, TAN S, ABDULLAH NA, JOHNS EJ: Exogenous hydrogen sulfide $\left(\mathrm{H}_{2} \mathrm{~S}\right)$ reduces blood pressure and prevents the progression of diabetic nephropathy in spontaneously hypertensive rats. Ren Fail 34: 203-210, 2012.

AIZAWA T, ISHIZAKA N, TAGUCHI J, NAGAI R, MORI I, TANG SS, INGELFINGER JR, OHNO M: Heme oxygenase-1 is upregulated in the kidney of angiotensin II-induced hypertensive rats: possible role in renoprotection. Hypertension 35: 800-806, 2000. 
ALENCAR JL, LOBYSHEVA I, CHALUPSKY K, GEFFARD M, NEPVEU F, STOCLET JC, MULLER B: S-nitrosating nitric oxide donors induce long-lasting inhibition of contraction in isolated arteries. J Pharmacol Exp Ther 307: 152-159, 2003.

ALSHEHRI A, BOURGUIGNON MP, CLAVREUL N, BADIER-COMMANDER C, GOSGNACH W, SIMONET S, VAYSSETTES-COURCHAY CH, CORDI A, FABIANI JN, VERBEUREN TJ, FÉLÉTOU M: Mechanisms of the vasorelaxing effects of CORM-3, a water-soluble carbon monoxide-releasing molecule: interactions with eNOS. Naunyn Schmiedebergs Arch Pharmacol 386: 185-196, 2013.

ALTAANY Z, MOCCIA F, MUNARON L, MANCARDI D, WANG R: Hydrogen sulfide and endothelial dysfunction: relationship with nitric oxide. Curr Med Chem 21: 3646-3661, 2014.

ARGAUD L, GARRIER O, LOUFOUAT J, GOMEZ L, COUTURE-LEPETIT E, GATEAU-ROESCH O, ROBERT D, OVIZE M: Second-generation sulfonylureas preserve inhibition of mitochondrial permeability transition by the mitochondrial $\mathrm{K}_{\text {ATP }}^{+}$opener nicorandil in experimental myocardial infarction. Shock 32: 247-252, 2009.

BALLIGAND JL, KELLY RA, MARSDEN PA, SMITH TW, MICHEL T: Control of cardiac muscle cell function by an endogenous nitric oxide signalling system. Proc Natl Acad Sci USA 90: 347-351, 1993.

BELIN DE CHANTEMELE EJ, STEPP DW: Influence of obesity and metabolic dysfunction on the endothelial control in the coronary circulation. J Mol Cell Cardiol 52: 840-847, 2012.

BEŁTOWSKI J: Hydrogen sulfide in pharmacology and medicine - An update. Pharmacol Rep 67: 647-658, 2015.

BEŁTOWSKI J, JAMROZ A, BORKOWSKA E: Heme oxygenase and carbon monoxide in the physiology and pathology of the cardiovascular system. Postepy Hig Med Dosw 58: 83-99, 2004.

BERNATOVA I: Endothelial dysfunction in experimental models of arterial hypertension: Cause or consequence? Biomed Res Int 2014: 598271, 2014.

BOISSIERE J, LEMAIRE MC, ANTIER D, COURTEIX D, BONNET P: Exercise and vasorelaxing effects of COreleasing molecules in hypertensive rats. Med Sci Sports Exerc 38: 652-659, 2006.

BOLLI R, BHATTI ZA, TANG XL, QIU Y, ZHANG Q, GUO Y, JADOON AK: Evidence that late preconditioning against myocardial stunning in conscious rabbits is triggered by the generation of nitric oxide. Circ Res 81: 42-52, 1997.

BOTROS FT, NAVAR LG: Interaction between endogenously produced carbon monoxide and nitric oxide in regulation of renal afferent arterioles. Am J Physiol Heart Circ Physiol 291: H2772-H2778, 2006.

BOUVET C, BELIN DE CHANTEMELE E, GUIHOT AL, VESSIÈRES E, BOCQUET A, DUMONT O, JARDEL A, LOUFRANI L, MOREAU P, HENRION D: Flow-induced remodeling in resistance arteries from obese Zucker rats is associated with endothelial dysfunction. Hypertension 50: 248-254, 2007.

BREDT DA, SNYDER SH: Isolation of nitric oxide synthetase, a calmodulin-requiring enzyme. Proc Natl Acad Sci USA 87: 682-685, 1990.

BUCHWALOW IB, SCHULZE W, KARCZEWSKI P, KOSTIC MM, WALLUKAT G, MORWINSKI R, KRAUSE EG, MÜLLER J, PAUL M, SLEZAK J, LUFT FC, HALLER H: Inducible nitric oxide synthase in the myocard. Mol Cell Biochem 217: 73-82, 2001.

BURLEY DS, COX CD, ZHANG J, WANN KT, BAXTER GF: Natriuretic peptides modulate ATP-sensitive $\mathrm{K}^{+}$channels in rat ventricular cardiomyocytes. Basic Res Cardiol 109: 402, 2014.

CACANYIOVA S, BERENYIOVA A, KRISTEK F: The role of hydrogen sulphide in blood pressure regulation. Physiol Res 65 (Suppl 3): S273-S289, 2016.

CALVERT JW, ELSTON M, NICHOLSON CK, GUNDEWAR S, JHA S, ELROD JW, RAMACHANDRAN A, LEFER DJ: Genetic and pharmacologic hydrogen sulfide therapy attenuates ischemia-induced heart failure in mice. Circulation 122: 11-19, 2010.

CHAN KH, NG MK, STOCKER R: Haem oxygenase-1 and cardiovascular disease: mechanisms and therapeutic potential. Clin Sci (Lond) 120: 493-504, 2011.

CHENG Y, NDISANG JF, TANG G, CAO K, WANG R: Hydrogen sulfide-induced relaxation of resistance mesenteric artery beds of rats. Am J Physiol Heart Circ Physiol 287: H2316-H2323, 2004.

CLARK JE, NAUGHTON P, SHUREY S, GREEN CJ, JOHNSON TR, MANN BE, FORESTI R, MOTTERLINI R: Cardioprotective actions by a water-soluble carbon monoxide-releasing molecule. Circ Res 93: 2-8, 2003. 
DECALUWÉ K, PAUWELSB, VERPOEST S, VAN DE VOORDE J: Divergent mechanisms involved in CO and CORM-2 induced vasorelaxation. Eur J Pharmacol 674: 370-377, 2012.

DESMARD M, FORESTI R, MORIN D, DAGOUASSAT M, BERDEAUX A, DENAMUR E, CROOK SH, MANN BE, SCAPENS D, MONTRAVERS P, BOCZKOWSKI J, MOTTERLINI R: Differential antibacterial activity against Pseudomonas aeruginosa by carbon monoxide-releasing molecules. Antioxid Redox Signalling 16: 153-163, 2012.

DING H, ALJOFAN M, TRIGGLE CR: Oxidative stress and increased eNOS and NADPH oxidase expression in mouse microvessel endothelial cells. J Cell Physiol 212: 682-689, 2007.

DI VILLA BIANCA RD, CIRINO G, SORRENTINO R: Hydrogen sulfide and urogenital tract. Handb Exp Pharmacol 230: 111-136, 2015.

DRÖGE W: Free radicals in the physiological control of cell function. Physiol Rev 82: 47-95, 2002.

ELSEY DJ, FOWKES RC, BAXTER GF: Regulation of cardiovascular cell function by hydrogen sulfide $\left(\mathrm{H}_{2} \mathrm{~S}\right)$. Cell Biochem Funct 28: 95-106, 2010.

EROY-EVELES AA, MASCHARAK PK: Nitric oxide-donating materials and their potential in pharmacological applications for site-specific nitric oxide delivery. Future Med Chem 1: 1497-1507, 2009.

FAILLI P, VANNACCI A, MANNELLI LDC, MOTTERLINI R, MASINI E: Relaxant effect of a water soluble carbon monoxide-releasing molecule (CORM-3) on spontaneously hypertensive rat aortas. Cardiovasc Drugs Ther 26: 285-292, 2012.

FERON O, BALLIGAND JL: Caveolins and the regulation of endothelial nitric oxide synthase in the heart. Cardiovasc Res 69: 788-797, 2006.

FORESTI R, HAMMAD J, CLARK JE, JOHNSON TR, MANN BE, FRIEBE A, GREEN CJ, MOTTERLINI R: Vasoactive properties of CORM-3, a novel water-soluble carbon monoxide-releasing molecule. $\mathrm{Br} J$ Pharmacol 142: 453-460, 2004.

FÖRSTERMANN U, POLLOCK JS, SCHMIDT HH, HELLER M, MURAD F: Calmodulin-dependent endotheliumderived relaxing factor/nitric oxide synthase activity is present in the particulate and cytosolic fractions of bovine aortic endothelial cells. Proc Natl Acad Sci USA 88: 1788-1792, 1991.

FUKUTO JM, CARRINGTON SJ, TANTILLO DJ, HARRISON JG, IGNARRO LJ, FREEMAN BA, CHEN A, WINK DA: Small molecule signalling agents: the integrated chemistry and biochemistry of nitrogen oxides, oxides of carbon, dioxygen, hydrogen sulfide, and their derived species. Chem Res Toxicol 25: 769-793, 2012.

FULTON D, HARRIS MB, KEMP BE, VENEMA RC, MARRERO MB, STEPP DW: Insulin resistance does not diminish eNOS expression, phosphorylation, or binding to HSP-90. Am J Physiol Heart Circ Physiol 287: H2384-H2393, 2004.

FURCHGOTT RF, ZAWADZKI JV: The obligatory role of endothelial cells in the relaxation of arterial smooth muscle by acetylcholine. Nature 288: 373-376, 1980.

GADALLA MM, SNYDER SH: Hydrogen sulfide as a gasotransmitter. J Neurochem 113: 14-26, 2010.

GARVIN JL, HERRERA M, ORTIZ PA: Regulation of renal $\mathrm{NaCl}$ transport by nitric oxide, endothelin, and ATP: clinical implications. Annu Rev Physiol 73: 359-376, 2011.

GORI T, PARKER JD: Nitrate-induced toxicity and preconditioning: a rationale for reconsidering the use of these drugs. J Am Coll Cardiol 52: 251-254, 2008.

GRAMBOW E, MUELLER-GRAF F, DELYAGINA E, FRANK M, KUHLA A, VOLLMAR B: Effect of the hydrogen sulfide donor GYY4137 on platelet activation and microvascular thrombus formation in mice. Platelets 25: 166-174, 2014.

HEART PROTECTION STUDY COLLABORATIVE GROUP: MRC/BHF Heart Protection Study of antioxidant vitamin supplementation in 20,536 high-risk individuals: a randomised placebo-controlled trial. Lancet 360: 23-33, 2002.

HINZ B, KUNTZE U, SCHRÖDER H: Pentaerithrityl tetranitrate and its phase I metabolites are potent activators of cellular cyclic GMP accumulation. Biochem Biophys Res Commun 253: 658-661, 1998.

HOLLENBERG SM: Vasodilators in acute heart failure. Heart Fail Rev 12: 143-147, 2007.

HORINAKA DS: Use of nicorandil in cardiovascular disease and its optimization. Drugs Springer Int Publ 71: 11051119, 2011. 
HOSOKI R, MATSUKI N, KIMURA H: The possible role of hydrogen sulfide as an endogenous smooth muscle relaxant in synergy with nitric oxide. Biochem Biophys Res Commun 237: 527-531, 1997.

IGNARRO LJ, BYRNS RE, WOOD KS: Biochemical and pharmacological properties of endothelium-derived relaxing factor and its similarity to nitric oxide radical. In: Mechanisms of Vasodilatation. PM VANHOUTTE (ed), Raven Press, New York, 1988, pp 427-435.

JOHNSON RA, LAVESA M, DESEYN K, SCHOLER MJ, NASJLETTI A: Heme oxygenase substrates acutely lower blood pressure in hypertensive rats. Am J Physiol Heart Circ Physiol 271: H1132-H1138, 1996.

JOHNSON RA, TERAN FJ, DURANTE W, PEYTON KJ, JOHNSON FK: Enhanced heme oxygenase-mediated coronary vasodilation in Dahl salt-sensitive hypertension. Am J Hypertens 17: 25-30, 2004.

KASHFI K, OLSON KR: Biology and therapeutic potential of hydrogen sulfide and hydrogen sulfide-releasing chimeras. Biochem Pharmacol 85: 689-703, 2013.

KIMURA H: Physiological role of hydrogen sulfide and polysulfide in the central nervous system. Neurochem Int 63: 492-497, 2013.

KIMURA H: Production and physiological effects of hydrogen sulfide. Antioxid Redox Signal 20: 783-793, 2014.

KNOWLES CJ, DIONNE M, CEBOVA M, PINZ IM: Palmitate-induced translocation of caveolin-3 and endothelial nitric oxide synthase in cardiomyocytes. OnLine J Biol Sci 11: 27-36, 2011.

KRAM L, GRAMBOW E, MUELLER-GRAF F, SORG H, VOLLMAR B: The anti-thrombotic effect of hydrogen sulfide is partly mediated by an upregulation of nitric oxide synthases. Thromb Res 132: e112-e117, 2013.

KUKOVETZ WR, HOLZMANN S, BRAIDA C, PÖCH G: Dual mechanism of the relaxing effect of nicorandil by stimulation of cyclic GMP formation and by hyperpolarization. J Cardiovasc Pharmacol 17: 627-633, 1991.

KULKARNI-CHITNIS M, NJIE-MBYE YF, MITCHELL L, ROBINSON J, WHITEMAN M, WOOD ME, OPERE CA, OHIA SE: Inhibitory action of novel hydrogen sulfide donors on bovine isolated posterior ciliary arteries. Exp Eye Res 134: 73-79, 2015.

LACER SA: Derivatives of isosorbid mononitrate as vasodilator agents with reduced tolerance. International Patent 2005.

LI H, WALLERATH T, MUNZEL T, FORSTEMANN U: Regulation of endothelial-type NO synthase expression in pathophysiology and in response to drugs. Nitric Oxide 7: 149-164, 2002.

LI L, MOORE PK: An overview of the biological significance of endogenous gases: new role for old molecules. Biochem Soc Trans 35: 1138-1141, 2007.

LI L, WHITEMAN M, GUAN YY, NEO KL, CHENG Y, LEE SW, ZHAO Y, BASKAR R, TAN CH, MOORE PK: Characterization of a novel, water-soluble hydrogen sulfide-releasing molecule (GYY4137): new insights into the biology of hydrogen sulfide. Circulation 117: 2351-2360, 2008.

LI L, FOX B, KEEBLE J, SALTO-TELLEZ M, WINYARD PG, WOOD ME: The complex effects of the slowreleasing hydrogen sulfide donor GYY4137 in a model of acute joint inflammation and in human cartilage cells. J Cell Mol Med 17: 365-376, 2013.

LI Q, LANCASTER JR: Chemical foundation of hydrogen sulfide biology. Nitric Oxide 35: 21-34, 2013.

LIPPI G, RASTELLI G, MESCHI T, BORGHI L, CERVELLIN G: Pathophysiology, clinics, diagnosis and treatment of heart involvement in carbon monoxide poisoning. Clin Biochem 45: 1278-1285, 2012.

LIU Z, HAN Y, LI L, LU H, MENG G, LI X, SHIRHAN M, PEH MT, XIE L, ZHOU S, WANG X, CHEN Q, DAI W, TAN CH, PAN S, MOORE PK, JI Y: The hydrogen sulfide donor, GYY4137, exhibits anti-atherosclerotic activity in high fat fed apolipoprotein E(-/-) mice. Br J Pharmacol 169: 1795-1809, 2013.

MA X, SAYED N, BEUVE A, VAN DEN AKKER F: NO and CO differentially activate soluble guanylyl cyclase via a heme pivot-bend mechanism. EMBO J 26: 578-588, 2007.

MAINES MD, TRAKSHEL GM, KUTTY RK: Characterization of two constitutive forms of rat liver microsomal heme oxygenase. Only one molecular species of the enzyme is inducible. J Biol Chem 261: 411-419, 1986.

MANN BE: Carbon monoxide: an essential signalling molecule. Top Organomet Chem 32: 247-285, 2010.

MARAZIOTI A, BUCCI M, COLETTA C, VELLECCO V, BASKARAN P, SZABÓ C, CIRINO G, MARQUES AR, GUERREIRO B, GONCĄLVES AML, SEIXAS JO, BEUVE A, ROMA CC, PAPAPETROPOULOS A: Inhibition of nitric oxide-stimulated vasorelaxation by carbon monoxide-releasing molecules. Arterioscler Thromb Vasc Biol 31: 2570-2576, 2011. 
MCCOUBREY WK JR, HUANG TJ, MAINES MD: Heme oxygenase-2 is a hemoprotein and binds heme through heme regulatory motifs that are not involved in heme catalysis. J Biol Chem 272: 12568-12574, 1997.

MEGSON IL, LESLIE SJ: LA-419, a nitric-oxide donor for the treatment of cardiovascular disorders. Curr Opin Invest Drugs 10: 276-285, 2009.

MOTTERLINI R, CLARK JE, FORESTI R, SARATHCHANDRA P, MANN BE, GREEN CJ: Carbon monoxidereleasing molecules - characterization of biochemical and vascular activities. Circ Res 90: 17-24, 2002.

MOTTERLINI R, MANN BE, JOHNSON TR, CLARK JE, FORESTI R, GREEN CJ: Bioactivity and pharmacological actions of carbon monoxide-releasing molecules. Curr Pharm Des 9: 2525-2539, 2003.

MOTTERLINI R, MANN BE, FORESTI R: Therapeutic applications of carbon monoxide-releasing molecules. Expert Opin Investig Drugs 14: 1305-1318, 2005.

MOTTERLINI R, HAAS B, FORESTI R: Emerging concepts on the anti-inflammatory actions of carbon monoxidereleasing molecules (CO-RMs). Med Gas Res 2: 28, 2012.

MUCHOVA L, WONG RJ, HSU M, MORIOKA I, VITEK L, ZELENKA J, SCHRÖDER H, STEVENSON DK: Statin treatment increases formation of carbon monoxide and bilirubin in mice: a novel mechanisms of in vivo antioxidant protection. Can J Physiol Pharmacol 85: 800-810, 2007.

MUNOZ-SANCHEZ J, CHANEZ-CARDENAS ME: A review on hemeoxygenase-2: focus on cellular protection and oxygen response. Oxid Med Cell Longev 2014: 1-16, 2014.

MUSAMEH MD, FULLER BJ, MANN BE, GREEN CJ, MOTTERLINI R: Positive inotropic effects of carbon monoxide-releasing molecules (CO-RMs) in the isolated perfused rat heart. Br J Pharmacol 149: 1104-1112, 2006.

MUSTAFA AK, SIKKA G, GAZI SK, STEPPAN J, JUNG SM, BHUNIA AK, BARODKA VM, GAZI FK, BARROW RK, WANG R, AMZEL LM, BERKOWITZ DE, SNYDER SH: Hydrogen sulfide as endotheliumderived hyperpolarizing factor sulfhydrates potassium channels. Circ Res 109: 1259-1268, 2011.

MUSTAFA MR, JOHNS EJ: The role of haem oxygenase in renal vascular reactivity in normotensive and hypertensive rats. J Hypertens 19: 1105-1111, 2001.

NACHARAJU P, TUCKMAN-VERNON C, MAIER KE, CHOUAKE J, FRIEDMAN A, CABRALES P, FRIEDMAN JM: A nanoparticle delivery vehicle for S-nitroso-N-acetyl cysteine: sustained vascular response. Nitric Oxide 27: 150-160, 2012.

NDISANG JF, WANG R: Mechanisms underlying selective regulation of blood pressure by HO-1 in hypertension. Hypertension 40: 315-321, 2002.

NDISANG JF, TABIEN HE, WANG R: Carbon monoxide and hypertension. J Hypertens 22: 1057-1074, 2004.

NDISANG JF, CHIBBAR R, LANE N: Heme oxygenase suppresses markers of heart failure and ameliorates cardiomyopathy in L-NAME-induced hypertension. Eur J Pharmacol 734: 23-34, 2014.

OLAS B: Carbon monoxide is not always a poison gas for human organism: Physiological and pharmacological features of CO. Chem Biol Interact 222: 37-43, 2014.

PACHER P, BECKMAN JS, LIAUDET L: Nitric oxide and peroxynitrite in health and disease. Physiol Rev 87: 315-424, 2007.

PAN TT, FENG ZN, LEE SW, MOORE PK, BIAN JS: Endogenous hydrogen sulfide contributes to the cardioprotection by metabolic inhibition preconditioning in the rat ventricular myocytes. $J$ Mol Cell Cardiol 40: 119-130, 2006.

PAN X, ZHANG Y, TAO S: Effects of Tai Chi exercise on blood pressure and plasma levels of nitric oxide, carbon monoxide and hydrogen sulfide in real-world patients with essential hypertension. Clin Exp Hypertens 37: 8-14, 2015.

PEERS C, STEELE DS: Carbon monoxide: a vital signalling molecule and potent toxin in the myocardium. $J$ Mol Cell Cardiol 52: 359-365, 2012.

PECHANOVA O, SIMKO F: Chronic antioxidant therapy fails to ameliorate hypertension: potential mechanisms behind. J Hypertens 27 (Suppl 6): S32-S36, 2009.

PECHANOVA O, SIMKO F: The role of nuclear factor kappa B and nitric oxide interaction in heart remodelling. J Hypertens 28 (Suppl 1): S39-S44, 2010. 
PECHÁNOVÁ O, REZZANI R, BABÁL P, BERNÁTOVÁ I, ANDRIANTSITOHAINA R: Beneficial effects of Provinols: cardiovascular system and kidney. Physiol Res 55 (Suppl 1): S17-S30, 2006.

PECHANOVA O, VARGA ZV, CEBOVA M, GIRICZ Z, PACHER P, FERDINANDY P: Cardiac NO signalling in the metabolic syndrome. Br J Pharmacol 172: 1415-1433, 2015.

PITCHUMONY TS, SPINGLER B, MOTTERLINI B, ALBERTO R: Syntheses, structural characterization and CO releasing properties of boranocarbonate $\left[\mathrm{H}_{3} \mathrm{BCO}_{2} \mathrm{H}\right]$-derivatives. Org Biomol Chem 8: 4849-4854, 2010.

POLHEMUS DJ, LEFER DJ: Emergence of hydrogen sulfide as an endogenous gaseous signalling molecule in cardiovascular disease. Circ Res 114: 730-737, 2014.

PUZSEROVA A, BERNATOVA I: Blood pressure regulation in stress: Focus on nitric oxide-dependent mechanisms. Physiol Res 65 (Suppl 3): S309-S342, 2016.

RADOMSKI MW, PALMER RM, MONCADA S: Glucocorticoids inhibit the expression of an inducible, but not the constitutive, nitric oxide synthase in vascular endothelial cells. Proc Natl Acad Sci USA 87: 10043-10047, 1990.

REBOUL C, THIREAU J, MEYER G, ANDRÉ L, OBERT P, CAZORLA O, RICHARD S: Carbon monoxide exposure in the urban environment: an insidious foe for the heart? Respir Physiol Neurobiol 184: 204-212, 2012.

ROCHETTE L, COTTIN Y, ZELLER M, VERGELY C: Carbon monoxide: mechanisms of action and potential clinical implications. Pharmacol Ther 137: 133-152, 2013.

RUIZ-HURTADO G, DELGADO C: Nitric oxide pathway in hypertrophied heart: new therapeutic uses of nitric oxide donors. J Hypertens 28 (Suppl 1): S56-S61, 2010.

SERAFIM RA, PRIMI MC, TROSSINI GH, FERREIRA EI: Nitric oxide: state of the art in drug design. Curr Med Chem 19: 386-405, 2012.

SHI YX, CHEN Y, ZHU YZ, HUANG GY, MOORE PK, HUANG SH, YAO T, ZHU YC: Chronic sodium hydrosulfide treatment decreases medial thickening of intramyocardial coronary arterioles, interstitial fibrosis, and ROS production in spontaneously hypertensive rats. Am J Physiol Heart Circ Physiol 293: H2093-H2100, 2007.

SHIBUYA N, TANAKA M, YOSHIDA M, OGASAWARA Y, TOGAWA T, ISHII K, KIMURA H: 3-Mercaptopyruvate sulfurtransferase produces hydrogen sulfide and bound sulfane sulfur in the brain. Antioxid Redox Signal 11: 703-714, 2009.

SHIBUYA N, KOIKE S, TANAKA M, ISHIGAMI-YUASA M, KIMURA Y, OGASAWARA Y, FUKUI K, NAGAHARA N, KIMURA H: A novel pathway for the production of hydrogen sulfide from D-cysteine in mammalian cells. Nat Commun 4: 1366, 2013.

SCHMIDT HH: NO, CO and OH. Endogenous soluble guanylyl cyclase-activating factors. FEBS Lett 307: 102-107, 1992.

SCHULZ R, NAVA E, MONCADA S: Induction and potential biological relevance of a $\mathrm{Ca}^{2+}$-independent nitric oxide synthase in the myocardium. Br J Pharmacol 105: 575-580, 1992.

SIKORA M, DRAPALA A, UFNAL M: Exogenous hydrogen sulfide causes different hemodynamic effects in normotensive and hypertensive rats via neurogenic mechanisms. Pharmacol Rep 66: 751-758, 2014.

SINGH S, PADOVANI D, LESLIE RA, CHIKU T, BANERJEE R: Relative contributions of cystathionine betasynthase and gamma-cystathionase to $\mathrm{H}_{2} \mathrm{~S}$ biogenesis via alternative trans-sulfuration reactions. Biol Chem 284: 22457-22466, 2009.

SONI H, PATEL P, RATH AC, JAIN M, MEHTA AA: Cardioprotective effect with carbon monoxide releasing molecule-2 (CORM-2) in isolated perfused rat heart: role of coronary endothelium and underlying mechanism. Vascul Pharmacol 53: 68-76, 2010.

SONI H, JAIN M, MEHTA AA: Mechanism(s) involved in carbon monoxide-releasing molecule-2-mediated cardioprotection during ischaemia-reperfusion injury in isolated rat heart. Indian J Pharm Sci 74: 281-291, 2012.

STEIN AB, GUO Y, TAN W, WU WJ, ZHU X, LI Q, LUO CH, DAWN B, JOHNSON TR, MOTTERLINI R, BOLLI $\mathrm{R}$ : Administration of a CO-releasing molecule induces late preconditioning against myocardial infarction. J Mol Cell Cardiol 38: 127-134, 2005. 
STEIN AB, BOLLI R, DAWN B, SANGANALMATH SK, ZHU Y, WANG O: Carbon monoxide induces a late preconditioning-mimetic cardioprotective and antiapoptotic milieu in the myocardium. J Mol Cell Cardiol 52: 228-236, 2012.

STONE JR, MARLETTA MA: Soluble guanylate cyclase from bovine lung: activation with nitric oxide and carbon monoxide and spectral characterization of the ferrous and ferric state. Biochemistry 33: 5636-5640, 1994.

SZABO C: Hydrogen sulphide and its therapeutic potential. Nat Rev Drug Discov 6: 917-935, 2007.

SZABO C: Gaseotransmitters: new frontiers for translational science. Sci Transl Med 2: 59ps54, 2010.

SZABO C, RANSY C, MÓDIS K, ANDRIAMIHAJA M, MURGHES B, COLETTA C, OLAH G, YANAGI K, BOUILLAUD F: Regulation of mitochondrial bioenergetic function by hydrogen sulfide. Part I. Biochemical and physiological mechanisms. Br J Pharmacol 171: 2099-2122, 2014.

SZCZESNY B, MÓDIS K, YANAGI K, COLETTA C, LE TRIONNAIRE S, PERRY A, WOOD ME, WHITEMAN M, SZABO C: AP39, a novel mitochondria-targeted hydrogen sulfide donor, stimulates cellular bioenergetics, exerts cytoprotective effects and protects against the loss of mitochondrial DNA integrity in oxidatively stressed endothelial cells in vitro. Nitric Oxide 41: 120-130, 2014.

TANG XQ, CHEN RQ, DONG L, REN YK, DEL SOLDATO P, SPARATORE A, LIAO DF: Role of paraoxonase-1 in the protection of hydrogen sulfide-donating sildenafil (ACS6) against homocysteine-induced neurotoxicity. J Mol Neurosci 50: 70-77, 2013.

TERAN FJ, JOHNSON RA, STEVENSON BK, PEYTON KJ, JACKSON KE, APPLETON SD, DURANTE W, JOHNSON FK: Heme oxygenase-derived carbon monoxide promotes arteriolar endothelial dysfunction and contributes to salt-induced hypertension in Dahl salt-sensitive rats. Am J Physiol 288: R615-R622, 2004.

THOMAS C, SVEHLA L, MOFFETT BS: Sodium-nitroprusside-induced cyanide toxicity in pediatric patients. Expert Opin Drug Saf 8: 599-602, 2009.

THORUP C, JONES CL, GROSS SS, MOORE LC, GOLIGORSKY MS: Carbon monoxide induces vasodilation and nitric oxide release but suppresses endothelial NOS. Am J Physiol 277: 882-889, 1999.

TIRZIU D, SIMONS M: Endothelium-driven myocardial growth or nitric oxide at the crossroads. Trends Cardiovasc Med 18: 299-305, 2008.

TORRES-RESGADO E, FOURET G, CARBONNEAU MA, LEGER CI: Peroxynitrite mild nitration of albumin and LDL-albumin complex naturally present in plasma and tyrosine nitration rate-albumin impairs LDL nitration. Free Radic Res 41: 367-375, 2007.

UNTEREINER AA, WU L, WANG R: The role of CO as a gasotransmitter in cardiovascular and metabolic regulation. In: Gasotransmitters: Physiology and Pathophysiology. HERMANN A, SITDIKOVA GF, WEIGER TM (eds), Springer, Berlin, Heidelberg, 2012, pp 37-70.

VILAHUR G, SEGALES E, CASANI L, BADIMON L: A novel antiischemic nitric oxide donor inhibits thrombosis without modifying haemodynamic parameters. Thromb Haemost 91: 1035-1043, 2004.

VRANKOVA S, BARTA A, PAROHOVA J, PECHANOVA O: Could NF-kappa B play a role in blood pressure regulation? Focused on L-NAME-induced hypertension. J Hypertens 27 (Suppl 4): S140, 2009.

WANG K, AHMAD S, CAI M, RENNIE J, FUJISAWA T, CRISPI F, BAILY J, MILLER MR, CUDMORE M, HADOKE PW, WANG R, GRATACÓS E, BUHIMSCHI IA, BUHIMSCHI CS, AHMED A: Dysregulation of hydrogen sulfide producing enzyme cystathionine gamma-lyase contributes to maternal hypertension and placental abnormalities in preeclampsia. Circulation 127: 2514-2522, 2013.

WANG R: Physiological implications of hydrogen sulfide: a whiff exploration that blossomed. Physiol Rev 92: 791-896, 2012.

WANG R: Gasotransmitters: growing pains and joys. Trends Biochem Sci 39: 227-232, 2014.

WANG R, WU L, WANG Z: The direct effect of carbon monoxide on K-Ca channels in vascular smooth muscle cells. Pflugers Archiv 434: 285-291, 1997.

WANG Y, ZHAO X, JIN H, WEI H, LI W, BU D, TANG X, REN Y, TANG C, DU J: Role of hydrogen sulfide in the development of atherosclerotic lesions in apolipoprotein E knockout mice. Arterioscler Thromb Vasc Biol 29: 173-179, 2009. 
WEI WB, HU X, ZHUANG XD, LIAO LZ, LI WD: GYY4137, a novel hydrogen sulfide-releasing molecule, likely protects against high glucose-induced cytotoxicity by activation of the AMPK/mTOR signal pathway in H9c2 cells. Mol Cell Biochem 389: 249-256, 2014.

WHITEMAN M, WINYARD PG: Hydrogen sulfide and inflammation: the good, the bad, the ugly and the promising. Expert Rev Clin Pharmacol 4: 13-32, 2011.

WHITEMAN M, LI L, ROSE P, TAN CH, PARKINSON DB, MOORE PK: The effect of hydrogen sulfide donors on lipopolysaccharide-induced formation of inflammatory mediators in macrophages. Antioxid Redox Signal 12: 1147-1154, 2010.

WHITEMAN M, LE TRIONNAIRE S, CHOPRA M, FOX B, WHATMORE J: Emerging role of hydrogen sulfide in health and disease: critical appraisal of biomarkers and pharmacological tools. Clin Sci (Lond) 121: 459-488, 2011.

WU L, WANG R: Carbon monoxide: Endogenous production, physiological functions, and pharmacological applications. Pharmacol Rev 57: 585-630, 2005.

YAN H, DU J, TANG C: The possible role of hydrogen sulfide on the pathogenesis of spontaneous hypertension in rats. Biochem Biophys Res Commun 313: 22-27, 2004.

YANG G, WU L, JIANG B, YANG W, QI J, CAO K, MENG Q, MUSTAFA AK, MU W, ZHANG S, SNYDER SH, WANG R: H2S as a physiologic vasorelaxant: hypertension in mice with deletion of cystathionine gammalyase. Science 322: 587-590, 2008.

YAO L, WANG P, CHEN M, LIU Y, ZHOU L, FANG X, HUANG Z: Carbon monoxide-releasing molecules attenuate postresuscitation myocardial injury and protect cardiac mitochondrial function by reducing the production of mitochondria! Reactive oxygen species in a rat model of cardiac arrest. $J$ Cardiovasc Pharmacol Ther 20: 330-341, 2015.

YOSHIDA T, TAKAHASHI S, KIKUCHI G: Partial purification and reconstitution of the heme oxygenase system from pig spleen microsomes. J Biochem 75: 1187-1191, 1974.

YUE ZJ, YU ZB: Cardioprotection by the inhibitory effect of nitric oxide. Sheng Li Xue Bao 63: 191-197, 2011.

ZAOBORNYJ T, GHAFOURIFAR P: Strategic localization of heart mitochondrial NOS: a review of the evidence. Am J Physiol Heart Circ Physiol 303: H1283-H1293, 2012.

ZHAO S, LIN Q, LI H, HE Y, FANG X, CHEN F, CHEN CH, HUANG Z: Carbon monoxide releasing molecule-2 attenuated ischemia/ reperfusion-induced apoptosis in cardiomyocytes via a mitochondrial pathway. Mol Med Rep 9: 754-762, 2014.

ZHAO W, ZHANG J, LU Y, WANG R: The vasorelaxant effect of $\mathrm{H}_{2} \mathrm{~S}$ as a novel endogenous gaseous $\mathrm{K}_{\text {ATP }}$ channel opener. EMBO J 20: 6008-6016, 2001.

ZHAO X, ZHANG LK, ZHANG CY, ZENG XJ, YAN H, JIN HF, TANG CS, DU JB: Regulatory effect of hydrogen sulfide on vascular collagen content in spontaneously hypertensive rats. Hypertens Res 31: 1619-1630, 2008.

ZHEN J, LU H, WANG XQ, VAZIRI ND, ZHOU XJ: Upregulation of endothelial and inducible nitric oxide synthase expression by reactive oxygen species. Am J Hypertens 21: 28-34, 2008.

ZHONG G, CHEN F, CHENG Y, TANG C, DU J: The role of hydrogen sulfide generation in the pathogenesis of hypertension in rats induced by inhibition of nitric oxide synthase. J Hypertens 21: 1879-1885, 2003.

ZHONG L, LV L, YANG J, LIAO X, YU J, WANG R, ZHOU P: The inhibitory effect of hydrogen sulfide on platelet aggregation and the underlying mechanisms. J Cardiovasc Pharmacol 64: 481-487, 2014.

ZICHA J, PECHÁNOVÁ O, CACÁNYIOVÁ S, CEBOVÁ M, KRISTEK F, TÖRÖK J, SIMKO F, DOBESOVÁ Z, KUNES J: Hereditary hypertriglyceridemic rat: a suitable model of cardiovascular disease and metabolic syndrome? Physiol Res 55 (Suppl 1): S49-S63, 2006.

ZOBI F: CO and CO-releasing molecules in medicinal chemistry. Future Med Chem 5: 175-188, 2013. 